\title{
Spiritual and religious aspects of torture and scalping among the Indian cultures in Eastern North America, from ancient to colonial times
}

0 nly a few decades ago a common perception prevailed that the historical Native Americans were very prone to violence and warfare. Scalping and torture were seen as a specific custom attached into their ideology and sociocultural ethos (Hans 1907). However in the 1960 s a completely reversed picture started to emerge, following the course of other worldwide movements, such as ethnic rights, pan-Indianism, ecological conscience, revisionist historiography and so on. Immediately the Native American people came to be seen as the victims of the European colonialism and the Whites were the bad guys who massacred innocent women and children, either at Sand Creek or in Vietnam. Books were written in which the historians pointed out that the practice of scalping was actually not present in the Americas before the whites came. This theory drew sustenance from some early colonial accounts, especially from the Dutch and New England colonies, where it was documented that a special bounty was offered for Indian scalps. According to this idea, the practice of scalping among the Indians escalated only after this. On the other hand, the blame fell on the Iroquois tribesmen, whose cruel fighting spread terror throughout the seventeenth century, when they expanded an empire in the north-eastern wilderness. This accords with those theorists who wanted to maintain a more balanced view of the diffusion of scalping and torture, agreeing that these traits were indeed present in Pre-Columbian America, but limited only to the Iroquoians of the east (Axtell \& Sturtevant 1986). But where does the truth lie? Somewhere in between, maybe? Usually a middle-ground approach into a historical dilemma proves to be best, but not always. Here, for instance, we may have a case in which the traditional first perception may be the right one, no matter how inconvenient it would be in its implications about the socio-political arena.

Colonial American history has been rewritten every now and then. Each age and time perceives it a little differently, depending on political propaganda and economic or racial issues etc. The poor historians try to do their 


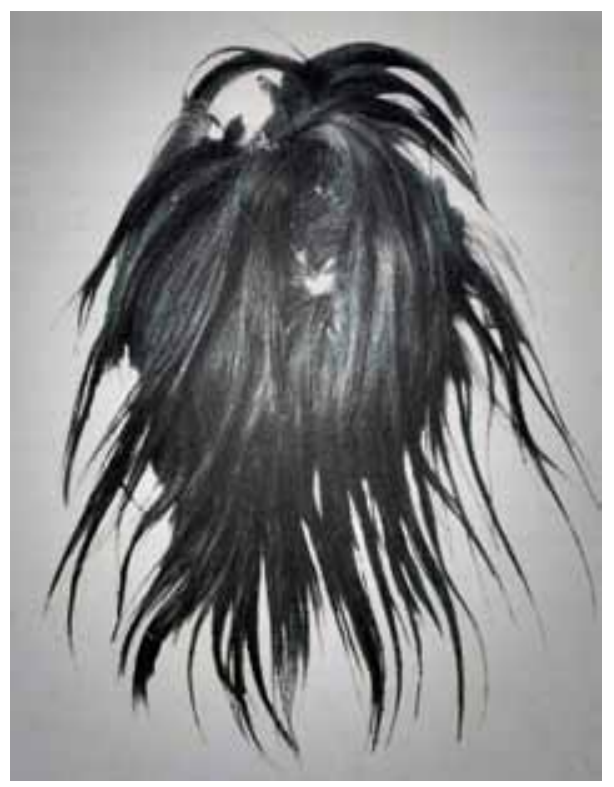

A genuine scalp (National Museum of Denmark). The photograph is computer enhanced by the author from Birket-Smith 1972. best however. And now, this historical panorama is changing once again. Starting this time in the 1980s, and in the field of archaeology especially, a completely new set of insights have arisen. Anthropologists are also reading their documents anew by using Ockham's razor instead. And what is the consequence of this?

There has been a secondary burial of the myth of Noble Savage and a return of the old Wild Indian idea, but this time stripped of its cartoon stereotypical attachments. This is of course a very simplified view. As a matter of fact, several characteristics from either side of the picture are present in the

contemporary image of the American Indian. We may say, at any rate, that this is the most realistic conception presented thus far. In a word, the Indians are now seen as being like any other human beings, with their usual mixture of vices and virtues. Understanding this, one may approach such a topic as scalping and torture without more bias than when reading of any practice of atrocities in human history (Keeley 1996, LeBlanc 1999, Osborn 2000).

Human violent behaviour exists in a cause and effect relationship. Violence in warfare is a norm. Sociocultural habits, taboos and laws are guiding its expressions. Spiritual and religious aspects determine markedly how, why and when the customary or institutionalized violence may occur. From the anthropological perspective, the practice of scalping and torture by Native Americans should be viewed more through its religious-spiritual aspects than in relation to its colonial historical implications, which are familiar and being popularized in the frontier warfare. Contextually it is actually much closer to the Mesoamerican cult of human sacrifice than with the Nazi Holocaust. Each of these are outstandingly brutal cases among the records of mankind of course, but they become understandable when all the historical, anthropological and religious-spiritual aspects are carefully studied and set into their proper places in our past (Mannix 1986, Scott 2006). 


\section{Prehistoric violence and warfare}

Scalping and torture were closely involved with warfare. That is why it is important how we perceive the nature of tribal warfare. Cumulating evidence is unveiling plainly that we have been far too optimistic, even utopian in our previous interpretations. All around the world archaeology has revealed locations of brutal prehistoric violence, sites of massacres and so on. Tribes which have been characterized as peaceful, are now seen as more warlike than their neighbours. In proportion to their populations, these tribal societies suffered far more casualties than ancient states and modern communities. Anthropology has also revealed that matrilineal societies were actually more prone to warfare than the patrilineal ones, a fact which sits uncomfortably with feminist theories (Arkush \& Allen 2006, Eller 2000, Guilaine \& Zammit 2005, Keeley 1996, LeBlanc 2003). This is particularly apparent in the Eastern Woodlands area of the North American continent. Here were the Iroquois, whose reputation extends worldwide across numerous cultural and sociohistorical arenas. These people provided a model for women's rights as well as the United States constitution, but still today there is a belief that they were the original scalpers and torturers in this primitive world. A new view is clearing this image of Iroquois brutality however, but only in its focus, since it extends the similar behaviour among their neighbours as well (Richter 1986).

Hardly any serious scholar today dares to doubt the idea that scalping was present in pre-Columbian America. Though the direct facts are few, a mountain of circumstantial evidence is accumulating from archaeological research. The most dramatic data comes from osteological examinations of burial grounds and massacre sites. One site in particular is a prime example. It is the Crow Creek archaeological ground in the Middle Missouri region, where the historical Mandan and Hidatsa tribes lived. It has been dated to around $1300 \mathrm{AD}$. What is astonishing here is a mass grave of about $500 \mathrm{men}$, women, and children, which almost all have been mutilated, tortured and scalped (Arkush \& Allen 2006, Case 2010, Dye 2009: 131-2, Keeley 1996, LeBlanc 1999, Smith 1991). This prehistoric killing field stands as a horrible Pol Potian kind of landmark in Native American history.

Skeletal data can give us only a partial idea of what has happened, and can testify primarily by means of the injures which have left markings on the bone. In reading the marks of prehistoric scalping for instance, one has to study skulls. There are a number of collections of comparative historical osteological data in museums, where confirmed cases of victims who have suffered scalping are present. Markings of scalping are very distinctive and 


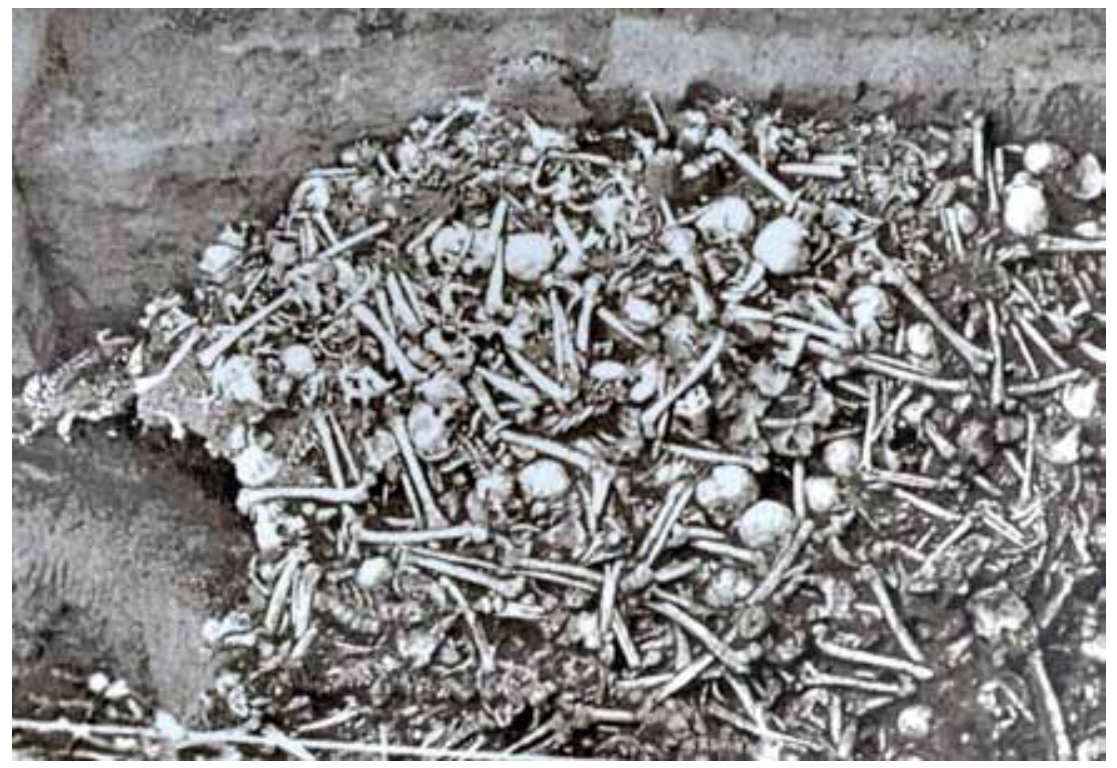

The Crow Creek site, beside Missouri in South Dakota, where remains of ca 500 bodies were found. Almost all were mutilated, tortured and scalped. This prehistoric massacre occurred ca $1325 \mathrm{AD}$. The copy of photograph is computer enhanced by the author from Keeley 1996.

one could not really find any other reasonable explanation for them. This has much to do with the act itself, which is most brutal and may even cause fatal bleeding. Even stone knives could carve deep furrows on skull bone. This kind of evidence has been excavated from most of the area of North America, indicating very dramatically that Native Americans practised scalping from times immemorial and on a wider scale than has been thought (Case 2010, LeBlanc 1999, Smith 1991). It is historically known that the ancient Scythians did this too, as well as some Germanic nations and tribes from Siberia; and, according to current data, certain folk in Central Asia and Scandinavia also (Denison 2000, Murphy et al. 2002, 'Scalping' in Wikipedia), but the North American Indians were unique indeed. We must therefore admit that these people fit into their popular stereotype on this particular point at least. Interestingly, the only other scalping Indians outside this vast area can be found thousands of miles away and are from the South American steppes of Chaco (Hodge 1910: 482).

And now, once we have put the Indians in their place amongst the other peoples of mankind, a question of the nature of scalping and torture must be presented. Anthropology uses labels such as 'religious' or 'spiritual' quite 
commonly and too lightly, whenever there is a need to interpret some newly excavated case which indicates evidence of prehistoric violence. A typical course of study proceeds in this way: in the first instance the excavating archaeologist usually comes to the right conclusions instantly by looking at the traumatic data in front of his eyes. Much later another scholar, maybe an anthropologist this time, reads the same data, but comes to a completely different reading by using the labels itemised above. Finally, a present-day archaeologist appears on the scene, reads the data once again, only to find that his previous colleague had it right at the beginning (LeBlanc 1999). A lesson may be drawn from this: Ockham's razor is a useful tool to have alongside the archaeologist's spade.

\section{The nature of Native American scalping and torture}

The question of the nature of scalping and torture among the North American Indian tribal societies is a complicated one. Universal answers are not available and the interpretations should be considered case by case. From the cross-cultural perspective certain aspects may be evident however, especially considering warfare in general and its consequences, where practice of atrocities is universal. Emic and ethic encounter each other here, and nowadays one may confidently interpret a violent behaviour plainly by itself, without any complicated explanation, except in pointing out motivations of sheer hate and the simple evilness of warfare. This is a part of the picture, and that is why we have to read much of the data from North America so carefully.

No doubt there also existed religious and spiritual aspects to the practice of scalping and torture among the Indians. Descriptive accounts can be read from early colonial sources, such as the Jesuit Relations for instance, which is an accurate document with certain interests in the Native American religion (as can be expected of the authors, who were clerics) (Thwaites 1896-1901). These documents synchronize with similar data gathered from primitive societies around the world and throughout history. Scalps and heads were primarily taken as war trophies, which were thought to bestow a supernatural, stimulating strength, stolen from an enemy. A returning war party which returned with a number of scalps was received with wild enthusiasm at home, and more so if there were enemy captives as well. A common fate for male captives was an immediate running of the gauntlet and thereafter a tortured death at the pole. Sometimes, if the captive exhibited outstanding heroism under torture he might be allowed to survive as an accepted, adopted member of the tribe. 
In the eastern areas of North America it was quite common, especially among the matrilineal tribes, that the active torturers were women and children. This is a logical element in humiliating a male victim, whose masculinity is attacked by every possible means (Friedrici 1993, Knowles 1993, Nadeau 1993). In fact, these tribes sometimes also practised brutal sexual raping of the male captives, in an effeminating act where they were 'made women'. On the other hand the American Indians only seldom raped women in war, which contrasts with the rest of the world (Trexler 1995). The reason for this may be in their general respect of women and their potential to raise children, who

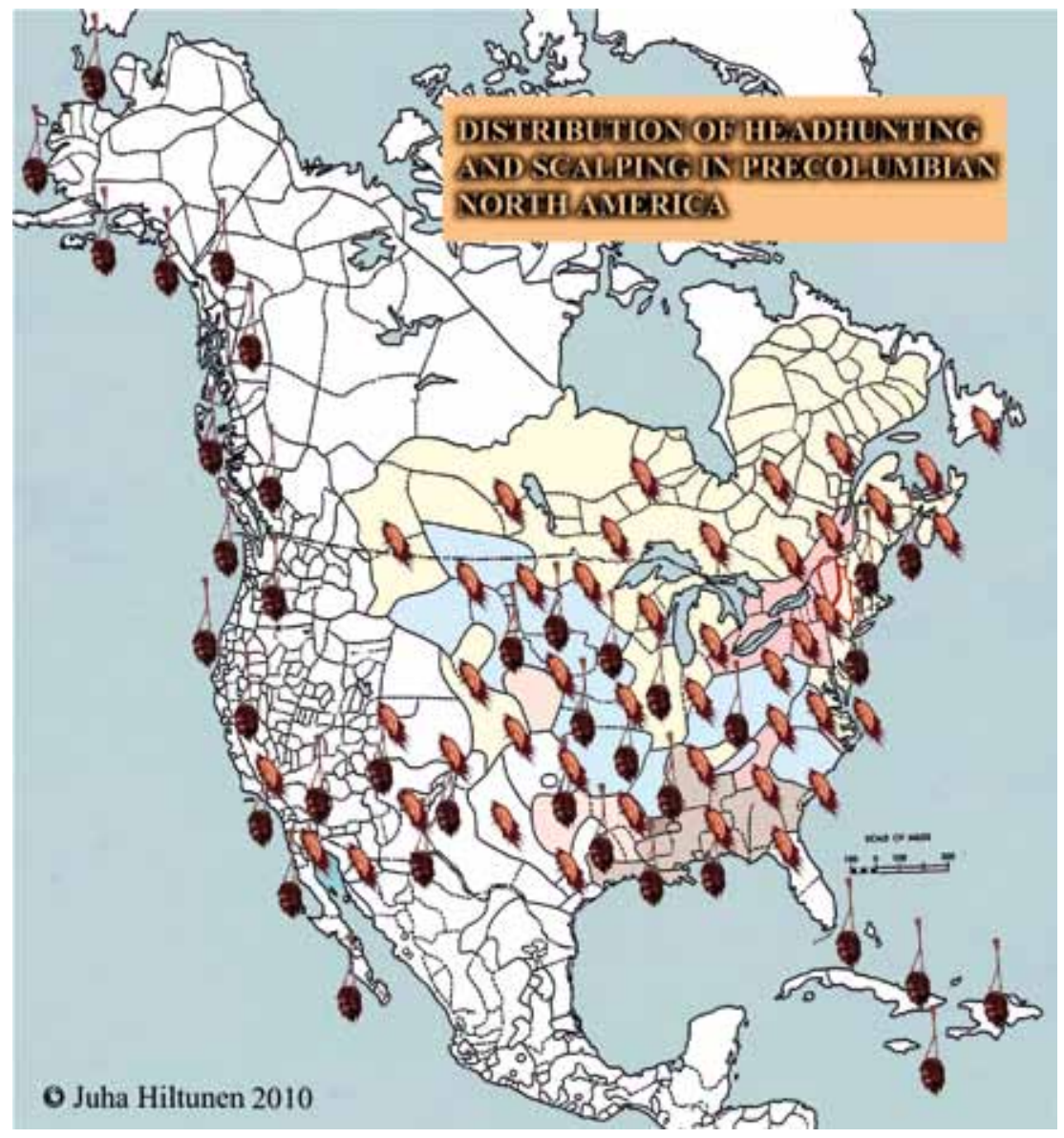

Distribution of headhunting and scalping in Pre-Columbian North America, yellow (Algonquins), light blue (Siouans), rose (Iroquoians), grey (Muskogheans). Designed by the author, 2010. 
were also highly valued. The Eastern Woodlands tribal world is very characteristic in this matter. Women and children were the prime targets as captives, not to be killed or tortured, but to be adopted into the tribe. Actually this adoption became institutionalized in the course of bloody tribal warfare, where numbers of casualties were sought to be compensated in this way. At

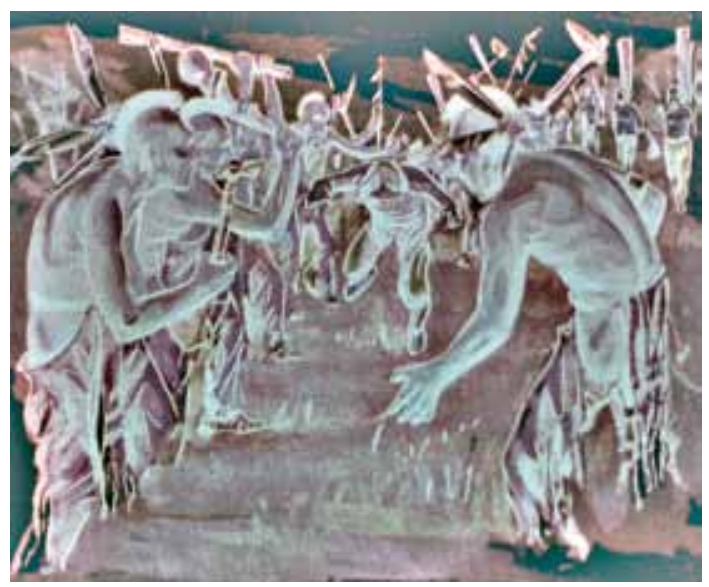

An artistic view of running the gauntlet, a test almost every male captive was forced to pass in the Eastern Woodlands. Original painting is computer enhanced by the author from Löfgren 1959.

least during colonial times when the tribal societies were reduced in numbers even more, it seldom occurred that very many captives were chosen to be tortured. Usually one, two, or a few more were selected, and on these occasions the ritualistic aspects were markedly present, when all the attention could be focused and enough time given over to a spectacle which could even last for days (Dye 2009, Friedrici 1993, Knowles 1993, Nadeau 1993, Osborn 2000).

The victims were treated with certain respect, which may seem strange. This is manifested especially in the way in which the torturers spoke with them. According to this etiquette, the victims were metaphorically seen as beloved relatives, whose fate was to be a sacrified offer (Knowles 1993). This respectful treatment of captives reflects that of the ancient Mesoamerican human sacrifice, a custom which may have spread early on to the north in this disguised form. Among the Aztecs, those to be sacrificed were usually captives of war, who by their suffering and death provided spiritual welfare to the empire state. Quite similarly the chosen victims among the Eastern Woodlands tribal societies were seen as sources of might and strength for each person present on the field of torture action. The braver an enemy the more power his torturers could gain. Here can be understood also the practical logic as to why women and children were usually not been killed this way. Their evident weakness to endure for any sustained period, made them 'bad medicine' to provide extra strength for male warriors on these occasions (Knowles 1993). 


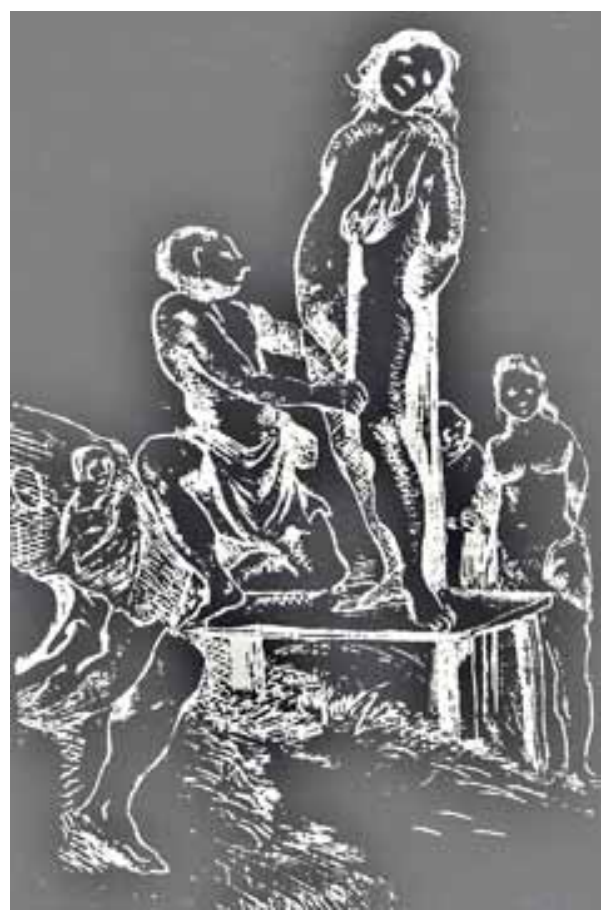

A sketch by David de Vries from the seventeenth century, in which an Iroquois village torture scene is illustrated. Picture is computer enhanced by the author from Wilbur 1995.
Woodlands warriors were actually mentally and physically trained from their childhood into a situation when one could be a captive himself and have to face a horrible death at the stake. In this training spiritual powers were sought in every possible way. These Woodlands warriors were indeed ready to die at any time, like Japanese samurais, or Muslim fanatics. An essential part of their training was physical endurance, which made them fearless and skilful fighters (Smith 1812, McNab 2010, Yager 1912). Their death at the stake in an enemy village should be seen as a battle in itself, and it had to be fought as bravely as possible. This was necessary, because only in this way could they maintain their societal tribal respect in the eyes of their enemies. Every one should learn his own death song, which must be chanted until the very end. It was the source of personal courage, like prayer for Christian martyrs (Knowles 1993). In this manner, ideally, the status quo of the Eastern Woodlands tribal spiritual worldview was maintained-like its Mesoamerican, more sophisticated prototype-by heroic deaths providing welfare to either sides of the arena-to the victims and to the tormentors. Interestingly, the Jesuits and other Christian missionaries found numbers of people among the Indians who were ready to listen to the teachings of the Gospels in which the story of a God who has been tormented to death at the stake for the welfare of mankind sounded familiar to their own belief system.

In fact, as an execution device, the Native American stake or torture pole has some parallels with the old world practice of impaling and crucifixion. In all these a victim is fixed into a pole. Impaling differs from the others in its fatal rapidity, while the Indian stake and the crucifixion-cross were closer 
each other as devices of torture instead of plain execution. Both are related in the ways in which the sufferings of victims were extended as long as possible and in the most humiliating manner (Hiltunen 2009: 101). But the Indian torture pole was set at the centre of the village for an audience similar to that of the gladiatorial arena of the Romans, while the crucifixion sites were outside town and usually without any specific spectators. This Indian pole does not have actual parallels, and this may be a reason why it became such a marked symbol of Native American cruelty, frequently presented in Western

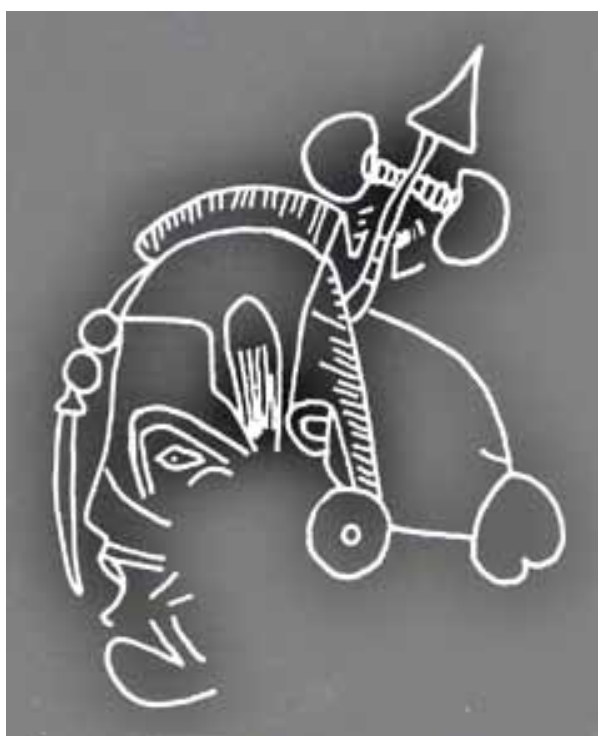

A fragment of Mississippian period shell gorget, in which an ancient warrior is figured. His head was shaved in historically well-known scalp lock style. Picture is computer enhanced by the author from Fundaburk \& Foreman 1985. drama, movies and comics.

Headhunting and scalping were related in an anthropological sense. The former seems to have been much older and more widespread custom, while scalping is restricted to certain culture areas. In North America their distribution overlaps in some areas, but both extended over a vast territory in this large continent. South American Indian tribes were frequently headhunters as opposed to their North American racial relatives who were mostly scalpers (Friedrici 1993). As has been stated, the evidence from archaeology is plentiful in indicating the presence of this practice for a very long time in this part of the world. Actually the first clearer cases have been found from the late archaic period, which means that scalping was invented here maybe as early as 2500 BC (Smith 1991). In the Eastern Woodlands a mound building civilization had its beginnings around this time and developed until its heyday, which happened a couple of centuries before the whites came into this area. At that time such cities as Cahokia, close to present day St Louis had a population of 40000 and all this country was much more crowded than at the beginning of the colonial era. The major cause of depopulation was the epidemics brought from Europe, especially smallpox. 


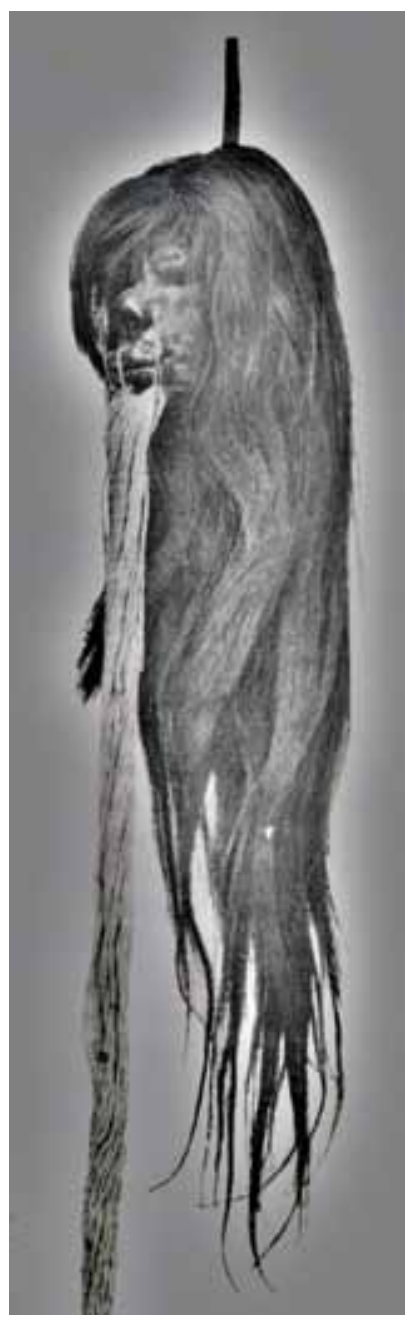

South American Jivaro-Indians are famous of their shrunken heads. Headhunting was common in South America, while scalping was practically unknown. The photograph is computer enhanced by the author from Birket-Smith 1972.
Archaeology has revealed that the intensity of intertribal warfare in the Eastern Woodlands was more escalated during the Mississippian period ( $\mathrm{ca}$ 900-1500) than almost any time during the colonial era (the only exception being the Iroquois expansion of seventeenth century). The aforementioned Crow Creek massacre site belongs to this timeline. These archaeological and ethnographical data indicate, however, that Native Americans did not possess any mental obstacles against using both torture and scalping on women too. It could really have been so, but again a focus of study must be directed in its proper time and area. These people experienced a profound change in their whole system of existence after the arrival of whites and their diseases, which almost annihilated the Indians. The survivors were only remnants of those major nations, which were remembered only through oral traditions and the haunting remains of their mysterious forest-growing, mound built cities all around the area. I presume therefore, that the scale of killing and captive sacrifice were markedly different during the colonial era than it was in Pre-Columbian times. Even the most horrible cases described in the early documents possibly could not have been compared with massacres such as that at Crow Creek, which is reminiscent of a distinctive total warfare belonging to complex societies. The historically known practise of torture and scalping by the Indians of this area may only have been a diminished reflection of the institutionalized violence which prevailed centuries ago, based on models which may have spread from Mesoamerica. This development could be seen as analogous with the medieval Europe of knights and tournaments, where 
fighting and violence were controlled by certain rules based on individual bravery and honour. When we read the colonial history of the Indian wars with this view in mind, a lot more sense can be found in the stories and one could really see this forest for its trees (Dye 2009, Fogelson 2004, Osborn 2000, Wilbur 1995, Washburn 1988, Ubelaker 2006).

Native Americans were very fond of their hair. Many tribes considered human hair as a specific locus of personal spiritual power, even the nest of the soul. The capture of one's soul by scalping had thus a certain amount of ideological truth to it. Other cases have been reported in which the fresh scalp has been offered as a sacrifice to supernatural beings. In the Eastern Woodlands especially, many tribes favoured the famous 'Mohawk' or 'Mohican' haircut, which leaves a lock of hair or roach on an otherwise shaven head. It seems to be very ancient in this area, because a lot of artwork from the early Adena and Hopewell mound building cultures include figures with this particular hairstyle. One of its functions may simply be practical, corresponding to the short haircuts soldiers are used to having everywhere. Another may lie in its provocative aspect for the enemy, by sending a visual message of one's courage. There may have been a certain self-protection as well, because in giving such a minimal space for scalping, multiple scalpings may be prevented and extra injures to the head likewise. On the other hand, there are some descriptions of how fellow tribesmen treated the survivors of scalping. According to these, some were kept as outcasts or even ghosts, and to whom a return to tribal community was prohibited. Others instead were treated with great respect, as these individuals were seen as touched by the spirits (Friedrici 1993, Nadeau 1993, Welch 1994). Anyhow, there existed a great variety of custom, attitude and ideology depending the culture area, tribe or even individuals. After all, this custom of taking scalps has been so deeply rooted in the cultural-historical ethos of the North American Indians, that it is even to be found in modern warfare. In fact, Native American soldiers and Mariners still took scalps during the both World Wars. This occurred also in the Korean, Vietnam and Gulf wars, and perhaps today in Iraq and Afghanistan as well (Welch 1994).

\section{Bibliography}

Arkush, Elizabeth N. \& Mark W. Allen (eds)

2006 The Archaeology of Warfare: Prehistories of Raiding and Conquest. Gainesville: University Press of Florida.

Axtell, James \& William C. Sturtevant

1986 The Unkindest Cut, or Who Invented Scalping? In: Roger L. Nichols (ed.), 
The American Indian Past and Present; pp. 47-6o. New York: Alfred A. Knopf.

\section{Birket-Smith, Kaj}

1972 Kulttuurin tiet 3. Helsinki: WSOY.

\section{Case, Troy}

2010 An Analysis of Scalping Cases and Treatment of the Victims Corpses in Prehistoric North America. http://www.dickshovel.com/scalp.html (accessed on 12 June 2010).

\section{Denison, Simon (ed.)}

2000 Origins of War: Mesolithic Conflict in Europe. British Archaeology 52, April Features. http://www.britarch.ac.uk/ba/ba52/ba52feat.html (accessed on 27 October 2010).

\section{Dye, David H.}

2009 War Paths, Peace Paths: An Archaeology of Cooperation and Conflict in Native Eastern North America. New York: Altamira Press.

\section{Eller, Cynthia}

2000 The Myth of Matriarchal Prehistory. Boston: Beacon Press.

Fogelson, Raymond D. (vol. ed.)

2004 Handbook of North American Indians. Vol. 14: Southeast. Washington: Smithsonian Institution.

\section{Friedrici, Georg}

1993 Scalping in America. Reprint by Iroqrafts Ltd. Indian Publications: Scalping and Torture. Ohsweken, Ontario. (First published in 1906.)

Fundaburk, E. L. \& M. D. Foreman (eds)

1985 Sun Circles and Human Hands. Fairhope, Alabama: Southern Publications.

\section{Guilaine, Jean \& Jean Zammit}

2005 The Origins of War: Violence in Prehistory. Oxford, UK: Blackwell Publishing. Hans, Fred M.

1907 The Great Sioux Nation: The Indians as Nature Made Them. Chicago: M.A. Donohue and Company Publishers.

\section{Hiltunen, Juha}

2009 Valokuva Jeesuksesta? Torinon käärinliina tieteen, historian ja Uuden testamentin valossa. Helsinki: Kirjapaja.

\section{Hodge, Frederick Webb}

1910 Handbook of American Indians North of Mexico. 2 vols. BAE, Bulletin 30. Washington: Smithsonian Institution.

\section{Keeley, Lawrence $\mathrm{H}$.}

1996 War Before Civilization: The Myth of the Peaceful Savage. New York: Oxford University Press.

\section{Knowles, Nathaniel}

1993 The Torture of Captives by the Indians of Eastern North America. Reprint by Iroqrafts Ltd. Indian Publications: Scalping and Torture. Ohsweken, Ontario. (First published in 1940.) 


\section{LeBlanc, Steven A.}

1999 Prehistoric Warfare in the American Southwest. Salt Lake City: The University of Utah Press.

2003 Constant Battles: The Myth of the Peaceful, Noble Savage. New York: St. Martin's Press.

\section{Löfgren, Åke}

1959 Maailman suurin seikkailu. Helsinki: Tammi.

\section{Mannix, Daniel P.}

1986 The History of Torture. New York: Dorset Press.

McNab, Chris

2010 The Native American Warrior 1500-1890 CE. Warriors of the World. New York: Amber Books Ltd.

\section{Murphy, Eileen, Ilia Gokhman \& Ludmila Barkova}

2002 Prehistoric Old World Scalping: New Cases from the Cemetery of Aymyriyg, South Siberia. In: American Journal of Archaeology 106 (1): 1-11.

\section{Osborn, William M.}

2000 The Wild Frontier. New York: Random House.

\section{Nadeau, Gabriel}

1993 Indian Scalping. Reprint by Iroqrafts Ltd. Indian Publications: Scalping and Torture. Ohsweken, Ontario. (First published in 1941.)

\section{Richter, Daniel K.}

1986 War and Culture: The Iroquois Experience. In: Roger L. Nichols (ed.), The American Indian Past and Present; pp. 105-26. New York: Alfred A. Knopf.

\section{Scalping}

nd Scalping. In: Wikipedia. http://en.wikipedia.org/wiki/Scalping (accessed on 12 June 2010).

Scott, George Ryley

2006 History of Torture Throughout the Ages. London: Torchstream Books.

\section{Smith, James}

1812 A Treatise of the Mode and Manner of Indian War. Paris, KY: Lyle.

Smith, Maria $\mathbf{O}$.

1991 The Earliest Scalping Victim in America. Research Notes 9 (1991). McClung Museum. http://mcclungmuseum.utk.edu/research/renotes/rn-ogtxt.htm (accessed on 12 June 2010).

\section{Thwaites, Reuben Gold}

1896-1901 Jesuit Relations and Allied Documents: Travels and Exploration of the Jesuit Missionaries in New France 1610-1791. 73 vols. Trans. from French. Cleveland: The Burrows Brother Company. Computerized transcript by Thom Mentrak. http://www.puffin.Creighton.edu/Jesuit/Relations (accessed on 27 October 2010).

\section{Trexler, Richard C.}

1995 Sex and Conquest. Oxford: Polity Press. 


\section{Turney-High, Harry H.}

1949 Primitive War. Columbia: University of South Carolina Press.

Ubelaker, Douglas H. (vol. ed.)

2006 Handbook of North American Indians. Vol. 3: Environment, Origins, and Population. Washington: Smithsonian Institution.

Washburn, Wilcomb E. (vol. ed.)

1988 Handbook of North American Indians. Vol. 4: History of Indian-White Relations. Washington: Smithsonian Institution.

\section{Welch, James}

1994 Killing Custer. Reprinted on the internet: 'Scalping, Torture, and Mutilation by Indians' (pp. 140-3). http://www.bluecorncomics.com/scalping.htm (accessed on 12 June 2010).

\section{Wilbur, Keith C.}

1995 The Woodland Indians. Guilford, CT: The Globe Pequot Press.

Yager, Willard E.

1912 The Onéota: The Red Man as Soldier. New York. 